\title{
APLIKASI BUAH MENGKUDU (Morinda citrifolia L) SEBAGAI BAHAN KOAGULAN ALAMI PADA LATEKS DI DESA AIR PUTIH KECAMATAN PUTRI HIJAU KABUPATEN BENGKULU UTARA
}

\section{NONI FRUIT (Morinda citrifolia L) APPLICATION AS NATURAL COAGULANT INGREDIENTS ON LATEX IN THE AIR PUTIH VILLAGE PUTRI HIJAU SUB DISTRICT NORTH BENGKULU}

\author{
Dharmawan Harahap ${ }^{1)}$ \\ 1) Program Studi Teknologi Pertanian, Fakultas Pertanian, Universitas Dehasen Bengkulu \\ Email : dharmawan77@gmail.com
}

\begin{abstract}
ABSTRAK
Lateks adalah suatu sistem koloid dimana partikel karet dilapisi oleh protein dan fosfolipid. Pembekuan atau koagulasi lateks bertujuan untuk mempersatukan (merapatkan) butiran-butiran karet yang terdapat dalam cairan lateks, supaya menjadi suatu gumpalan atau koagulan. Bahan alternatif yang bisa digunakan berupa sari buah mengkudu yang umumnya mempunyai $\mathrm{pH}$ yang asam yaitu 3,6-4,3. Telak dilaksanakan penelitian tentang penggunana buah mengkudu sebagai bahan koagulan alami pada lateks.

Metode dalam penelitian ini yaitu penyortiran, pemerasan, pemeraman, dan penggumpalan. Perlakuan pada setiap sampel yaitu konsetrasi sari mengkudu tanpa pemeraman dan dengan pemeraman selama 7 hari $(80 \%$, 90\% dan 100\%). Analisa yang dilakukan dalam penelitian berupa plastisitas awal, plastisitas retensi indeks, kadar kotoran, kadar abu dan kadar air.

Hasil analisa terhadap plastisitas awan (Po) dengan perlakuan ekstrak mengkudu tanpa pemeraman dan pemeraman sebanyak $0 \mathrm{ml}, 80 \mathrm{ml}, 90 \mathrm{ml}$ dan $100 \mathrm{ml}$ berpengaruh terhadap nilai Po yang dihasilkan yaitu dengan rerata berkisar antara 24,00 hingga 29,00, hasil analisa terhadap plastisitas retensi indeks (PRI)

berkisar antara 65,00 hingga 84,00, analisa terhadap kadar abu berkisar antara 0,21\% hingga $0,44 \%$, anailsa terhadap kadar kotoran berpengaruh terhadap kadar kotoran yang dihasilkan yaitu berkisar antara $0,01 \%$ hingga $0,09 \%$ dan analisa terhadap kadar air berkisar antara $28,83 \%$ hingga $41,78 \%$.
\end{abstract}

Kata kunci : lateks , koagulan, sari mengkudu

\section{ABSTRACT}

Latex is a colloid system in which the rubber particles coated by proteins and phospholipids. The aimed of freezing or latex coagulation is to unify (tighten) granules contained in the liquid rubber latex, so that became a blob or a coagulant. Alternative materials that can be used of noni extract which generally have acidic pH namely 3.6 to 4.3. Therefore, it carried out the research on the use noni fruit as a coagulant natural ingreadients of latex. 
The method in this research are sorting, extortioning, curing, and clotting. Treatment in each sample namely of noni extract concentration without curing and curing for 7 days (80\%, 90\% and 100\%). The analysis is conducted in the form of plasticity research early, plasticity retention index, levels of dirt, ash and moisture content.

Results of analysis from cloud plasticity (Po) with of noni extract treatment without curing and curing as many as $0 \mathrm{ml}, 80 \mathrm{ml}, 90 \mathrm{ml}$ and $100 \mathrm{ml}$ of influence on resulting value of Po namely the average ranged between 24.00 to 29.00. The analysis of plasticity retention index (PRI) ranged between 65.00 to 84.00, an analysis of the ash content ranged between $0.21 \%$ to $0.44 \%$, an analysis on levels of impurities influence on levels of manure produced ranged between 0, 01\% up to $0.09 \%$ and the analysis of the moisture ranged between $28.83 \%$ to $41.78 \%$.

Keywords: coagulant, noni extract, latex

\section{PENDAHULUAN}

Lateks adalah suatu sistem koloid dimana partikel karet dilapisi oleh protein dan fosfolipid. Protein ini akan memberikan muatan negatif yang mengelilingi partikel karet sehingga mencegah terjadinya interaksi antara sesama partikel karet, dengan demikian sistem koloid lateks akan tetap stabil. Namun dengan adanya mikroorganisme maka protein yang terdapat dalam partikel karet akan rusak dan terjadilah interaksi antara partikel karet membentuk flokulasi dan gumpalan (Zahara, 2005).

Pembekuan atau koagulasi bertujuan untuk mempersatukan (merapatkan) butiran-butiran karet yang terdapat dalam cairan lateks, supaya menjadi suatu gumpalan atau koagulan. Komposisi kimia lateks segar secara garis besar adalah 25-40\% karet dan 60-75\% merupakan bahan bukan karet. Kandungan bukan karet ini selain air adalah protein (globulin dan havein), karbohidrat (sukrosa, glukosa, galaktosa dan fruktosa), lipida (gliserida, sterol, dan fosfolipida). Komposisi ini bervariasi tergantung pada jenis tanaman, umur tanaman, musim, sistem deres dan penggunaan stimulan (Ompusungguh, et al, 1989).

Dalam proses penggumpalan lateks, terjadi perubahan sol ke gel dengan pertolongan zat penggumpal. Pada sol karet terdispersi di dalam serum, tetapi pada gel karet di dalam lateks. Penggumpalan dapat terjadi dengan penambahan asam (menurunkan $\mathrm{pH}$ ), sehingga koloid karet mencapai titik isoelektrik dan terjadilah penggumpalan. Penambahan elektrolit yang bermuatan positif juga dapat menetralkan muatan 
negatif dari partikel karet dan menggumpalkan karet (Ompusungguh, et al, 1989).

Secara umum bahan penggumpal lateks yang selama ini banyak digunakan adalah asam formiat. Penggumpalan dengan asam formiat dapat menghasilkan karet dengan sifat teknis yang baik. Dengan alasan harga yang mahal dan ketersediaan yang langka, masih banyak petani karet yang tidak menggunakan asam formiat sebagai bahan penggumpal. Mereka lebih cenderung memakai bahan penggumpal lain, seperti asam sulfat $\left(\mathrm{H}_{2} \mathrm{SO}_{4}\right)$, tawas dan bahan penggumpal alami. Sehingga membuka peluang bagi pengembangan bahan penggumpal alternatif. Bahan alternatif yang digunakan berupa sari buah mengkudu yang umumnya mempunyai $\mathrm{pH}$ yang asam.

Bahan alternatif yang digunakan berupa sari buah mengkudu yang umumnya mempunyai $\mathrm{pH}$ yang asam yaitu 3,6-4,3 (Rizky, dkk. 2013). Sehingga pentingnya penelitian tentang variasi mengkudu matang dan mengkudu peram sebagai bahan alternatif penggumpal lateks kebun sebagai pengganti asam formiat.

\section{METODE PENELITIAN}

Alat
Alat yang digunakan dalam penelitian ini yaitu pisau, nampan, toples, saringan, talenan dan pisau. Peralatan dalam analisa yaitu oven. cawan platina, desikator, pembakar listrik, timbangan, tanur dan pencepit cawan.

\section{Bahan}

Bahan yang digunakan dalam penelitian ini yaitu lateks dan buah mengkudu yang matang dipohon diperoleh di Desa Air Putih Kecamatan Putri Hijau Kabupaten Bengkulu Utara

\section{Prosedur Penelitian}

\section{Persiapan Bahan Baku}

Tahap pertama mempersiapkan lateks basah dan sari mengkudu yang matang maupun yang telah diperam. Lateks langsung diambil dari kebun karet di sekitar Desa Air Putih. Lateks diambil di pagi hari dengan harapan untuk mendapatkan lateks yang belum mengalami prakoagulasi. Lateks yang telah diambil kemudian disaringlalu dimasukkan ke dalam beker glass $100 \mathrm{ml}$ per sampel.

\section{Proses Persiapan Sari Mengkudu}

Proses penggolahan sari mengkudu sebagai berikut:

\section{Sari mengkudu matang}

1. Mengkudu yang diperoleh disortir 
2. Mengkudu matang selanjutnya diperas sehingga didapatkan sarinya tanpa ada penambahan air.

3. Sari mengkudu matang yang didapat kemudian dilanjukan ke tahap pencampuran antara sari mengkudu matang dengan lateks sesuai dengan takaran yaitu $80 \mathrm{ml}, 90 \mathrm{ml}$ dan 100 $\mathrm{ml}$.

\section{Sari mengkudu peram}

1. Mengkudu yang diperoleh disortir

2. Mengkudu selanjutnya diperam selama 7 hari.

3. Mengkudu peram diperas dan dipisahkan sarinya.

4. Sari mengkudu peram dicampurkan dengan lateks dengan takaran $80 \mathrm{ml}$, $90 \mathrm{ml}$ dan $100 \mathrm{ml}$

5. Dilakukan pengamatan/pencatatan hasil.

\section{Analisa Penelitian}

Adapun analisa dalam penelitian ini yaitu:

1. Plastisitas Awal (Po)

2. Plastisitas Retensi Index (PRI)

3. Kadar Kotoran

4. Analisa Kadar Abu (Safitri, 2010)

5. Analisa Kadar Air (Anonim, 2013)

\section{Analisis Data}

Untuk mengetahui pengaruh sari mengkudu matang dan peram terhadap penggumpalan lateks dengan pengujian PO, PRI, kadar kotoran, kadar air, kadar abu, dengan dua faktor perlakuan yaitu : Waktu peram sari mengkudu

P1 : Sari mengkudu tanpa pemeraman

P2 : Sari mengkudu dengan pemeraman 7 hari

V1 : Volume bahan penggumpalan $80 \mathrm{ml}$ V2 : Volume bahan penggumpal $90 \mathrm{ml}$ V3 : Volume bahan penggumpal $100 \mathrm{ml}$ Komposisi sari mengkudu dan lateks: P0 = Sari mengkudu $0 \mathrm{ml}:$ Lateks $100 \mathrm{ml}$ P1V1 = Sari mengkudu tanpa peram 80 $\mathrm{ml}:$ Lateks $100 \mathrm{ml}$ P1V2 = Sari mengkudu tanpa peram 90 $\mathrm{ml}$ : Lateks $100 \mathrm{ml}$

P1V3 = Sari mengkudu tanpa peram 100 $\mathrm{ml}$ : Lateks $100 \mathrm{ml}$

P2V1 = Sari mengkudu peram $80 \mathrm{ml}$ : Lateks $100 \mathrm{ml}$

P2V2 = Sari mengkudu peram $90 \mathrm{ml}$ : Lateks $100 \mathrm{ml}$ P2V3 = Sari mengkudu Peram $100 \mathrm{ml}$ : Lateks $100 \mathrm{ml}$

\section{HASIL DAN PEMBAHASAN}

\section{Nilai Plastistas Awal (Po) Lump}

Hasil penelitian yang telah dilakukan terhadap pengaruh ekstrak sari mengkudu (Morinda citrifolia L) terhadap lateks diperoleh nilai plastisitas awal (Po) yang dipaparkan pada tabel 1. 
Tabel 1. Nilai Plastisitas Awal (Po) Lump

\begin{tabular}{|c|c|c|}
\hline $\begin{array}{c}\text { Penambahan } \\
\text { Ekstrak Mengkudu }\end{array}$ & Tanpa Pemeraman & $\begin{array}{c}\text { Melalui Pemeraman } \\
\text { 7 Hari }\end{array}$ \\
\hline $80 \mathrm{ml}$ & $24,00^{\mathrm{c}}$ & $24,00^{\mathrm{c}}$ \\
$90 \mathrm{ml}$ & $24,00^{\mathrm{c}}$ & $25,00^{\mathrm{b}}$ \\
$100 \mathrm{ml}$ & $24,00^{\mathrm{c}}$ & $24,00^{\mathrm{c}}$ \\
\hline Kontrol & \multicolumn{2}{|c|}{$29,33^{\mathrm{a}}$} \\
\hline
\end{tabular}

Ket : Angka yang diikuti kode huruf yang berbeda menunjukkan adanya perbedaan yang nyata pada taraf signifikan $5 \%$.

Plastisitas awal adalah plastisitas karet mentah yang langsung diuji tanpa perlakuan khusus sebelumnya, yang ditentukan dengan Wallace Plastimeter. Pada perlakuan ekstrak mengkudu tanpa pemeraman dengan konsentrasi $80 \mathrm{ml}, 90$ $\mathrm{ml}$ dan $100 \mathrm{ml}$ tidak memberikan pengaruh yang nyata terhadap nilai plastisitas awal, sedangkan perlakuan ekstrak mengkudu dengan pemeraman selama 7 hari dengan konsetrasi $80 \mathrm{ml}, 90$ $\mathrm{ml}$ dan $100 \mathrm{ml}$ memberikan pengaruh yang nyata terhadap nilai plastisitas awal.

Penambahan konsentrasi ekstrak sari mengkudu dengan perlakuan $0 \mathrm{ml}$ menunjukkan nilai maksimum Po sebesar 29, 33 , perlakuan dengan sari mengkudu tanpa pemeraman sebanyak $(80 \mathrm{ml}, 90$ mldan $100 \mathrm{ml}$ ) dan sari mengkudu peram (80 ml dan $100 \mathrm{ml}$ ) menunjukkan nilai minimum Po yaitu 24,00 dan penambahan sari mengkudu dengan perlakuan pemeraman sebanyak $90 \mathrm{ml}$ dengan nilai
Po 25,00. Dimana penambahan ekstrak mengkudu dengan perlakuan pemeraman berpengaruh terhadap nilai plastisitas awal.

Perlakuan dengan ekstrak mengkudu tanpa peram dan pemeraman dengan volume $80 \mathrm{ml}, 90 \mathrm{ml}$ dan $100 \mathrm{ml}$ penambahan dalam lateks masih memiliki banyak mengandungan logam kalsium, dimana dengan adanya logam kalsium ini akan mempercepat terjadinya oksidasi oleh oksigen di atmosfer dalam keadaan karet kering sehingga menyebabkan pemecahan rantai hidrokarbon karet sehingga molekul karet menjadi pendek dan karetnya lunak (Kartowardoyo, 1980). Karet yang mempunyai Po yang tinggi, mempunyai rantai molekul yang tahan terhadap oksidasi. Sedangkan yang mempunyai Po yang rendah mudah teroksidasi menjadi karet lunak (Walujuno, 1972). Plastistas awal yang tinggi lebih dikehendaki karena karet 
lebih tahan terhadap oksidasi, nilai plastistas awal dengan perlakuan ekstrak mengkudu tenpa peram dan melalui pemeraman $(80 \mathrm{ml}, 90 \mathrm{ml}$ dan $100 \mathrm{ml})$ tersebut memenuhi SIR-20-1990 dimana maksimum nilai plastisitas awal (Po) sebesar 30 .

\section{Nilai Plastis Retensi Index (PRI) Lump}

Hasil penelitian menunjukkan nilai plastis retensi index lump dapat dilihat pada tabel 2. Plastisitas retensi Index (PRI) adalah suatu ukuran ketahanan karet terhadap pengusangan atau oksidasi pada suhu tinggi. Semakin tinggi nilai plastistas retensi indeks maka mutu karet semakin baik karena karet tahanan terhadap degradasi oleh oksidasi pada suhu tinggi (Walujono, 1970) . Faktor utama yang berpengaruh terhadap nilai plastisitas retensi index adalah zat peroksida (logamlogam) dan zat-zat anti oksidan (protein dan senyawa lain yang teradsorbsi pada karet). Penambahan ekstrak sari mengkudu dengan perlakuan tanpa pemeraman dan pemeraman buah mengkudu mempengaruhi peningkatan terhadap nilai plastistas ritensi index (PRI) pada lateks jika dibandingnkan dengan perlakuan kontrol $0 \mathrm{ml}$. Perlakuan sari mengkudu tanpa pemeraman dan melalui pemeraman menunjukkan perbedaan yang nyata terhadap nilai PRI yang dihasilkan, sedangkan perlakuan volume mengkudu sebanyak $80 \mathrm{ml}, 90 \mathrm{ml}$ dan $100 \mathrm{ml}$ tidak beda nyata terhadap nilai PRI yang dihasilkan.

Tabel 2. Nilai Plastisitas Retensi Index (PRI) Lump

\begin{tabular}{|c|c|c|}
\hline $\begin{array}{c}\text { Penambahan } \\
\text { Ekstrak Mengkudu }\end{array}$ & Tanpa Pemeraman & $\begin{array}{c}\text { Melalui Pemeraman } \\
\mathbf{7 ~ H a r i}\end{array}$ \\
\hline $80 \mathrm{ml}$ & $79,00^{\mathrm{b}}$ & $83,00^{\mathrm{a}}$ \\
$90 \mathrm{ml}$ & $79,00^{\mathrm{b}}$ & $84,00^{\mathrm{a}}$ \\
$100 \mathrm{ml}$ & $79,00^{\mathrm{b}}$ & $83,00^{\mathrm{a}}$ \\
\hline Kontrol & \multicolumn{2}{|c|}{$65,00^{\mathrm{c}}$} \\
\hline
\end{tabular}

Ket : Angka yang diikuti kode huruf yang berbeda menunjukkan adanya perbedaan yang nyata pada taraf signifikan $5 \%$. 
Penambahan larutan asam yaitu ekstrak sari mengkudu mengakibatkan terjadinya penurunan $\mathrm{pH}$ lateks. Dimana penurunan $\mathrm{pH}$ lateks tersebut terjadi karena terbentuknya asam-asam hasil penguraian bakteri. Adanya ion logam akan mempercepat proses oksidasi karet oleh udara yang menyebabkan terjadinya pengusangan karet pada suhu tinggi sehingga karet menjadi lebih lunak dan mudah putus.

Penambahan ekstrak sari mengkudu dengan perlakuan tanpa pemeraman dengan konsentrasi $80 \mathrm{ml}, 90 \mathrm{ml}$ dan 100 ml menunjukkan nilai PRI 79,00 lebih kecil jika dibandingkan dengan perlakuan ekstrak mengkudu yang diperam. Nilai dari plastisitas retensi index (PRI) tersebut memenuhi SIR-20-1990 dimana minimum nilai PRI yaitu 40 .

\section{Kadar Abu Lump}

Hasil penelitian menunjukkan kadar abu lump dapat dilihat pada tabel 3. Kadar abu merupakan gambaran minimum dalam sejumlah mineral yang ada dalam karet. Kadar abu karet bervariasi berupa karbonat dan fosfat dari kalium, magnesium, kalsium, natrium, dan beberapa unsur lain dalam jumlah yang berbeda-beda. Beberapa bahan mineral dalam karet meninggalkan abu yang dapat mengurangi ketahana karet lentur dari vulkanisasi karet alami. Penambahan ekstrak sari mengkudu dengan perlakuan tanpa pemeraman menunjukkan nilai kadar abu yang lebih kecil yaitu $0,21 \%$ hingga $0,24 \%$ jika dibandingakan dengan perlakuan ekstrak sari mengkudu yang diperam yaitu $0,38 \%$ hingga $0,44 \%$. Kandungan kadar abu dapat dipengaruhi oleh ion logam yang terdapat pada sari mengkudu, dimana semakin tinggi konsentrasi ion logam akan semakin tinggi kadar abu lateks . Faktor pengolahan dapat mempengaruhi kadar abu, dimana makin besar tingkat pengolahan lateks maka kadar abu semakin rendah misalkan lateks yang digumapalkan tanpa pengenceran mempunyai kadar abu yang lebih tinggi dari pada dengan pengenceran (Kartowardoyo, 1980). Nilai dari kadar abu tersebut memenuhi SIR-20-1990 yaitu kandungan kadar abu maksimum 1,0\%. Berdasarkan hasil uji lanjut DMRT menunjukkan bahwa setiap perlakuan penambhan ekstrak mengkudu peram dan tanpa pemeraman mempengaruhi hasil analisa kadar abu lateks.Sehingga penambahan ekstrak sari mengkudu dengan perlakuan tanpa pemeraman dan peram sebanyak $80 \mathrm{ml}, 90 \mathrm{ml}$ dan $100 \mathrm{ml}$ berpengaruh terhadap kandungan kadar abu karet yang dihasilkan. 
Tabel 3. Nilai Kadar Abu Lump

\begin{tabular}{|c|c|c|}
\hline $\begin{array}{c}\text { Penambahan } \\
\text { Ekstrak Mengkudu }\end{array}$ & Tanpa Pemeraman & $\begin{array}{c}\text { Melalui Pemeraman } \\
\text { 7 Hari }\end{array}$ \\
\hline $80 \mathrm{ml}$ & $0,21^{\mathrm{e}}$ & $0,44^{\mathrm{a}}$ \\
$90 \mathrm{ml}$ & $0,21^{\mathrm{e}}$ & $0,44^{\mathrm{a}}$ \\
$100 \mathrm{ml}$ & $0,24^{\mathrm{d}}$ & $0,38^{\mathrm{b}}$ \\
\hline Kontrol & \multicolumn{2}{|c|}{$0,34^{\mathrm{c}}$} \\
\hline
\end{tabular}

Ket : Angka yang diikuti kode huruf yang berbeda menunjukkan adanya perbedaan yang nyata pada taraf signifikan 5\%.

\section{Kadar Kotoran Lump}

Hasil penelitian menunjukkan bahwa kadar kotoran lump dapat dilihat pada tabel 4. Kotoran adalah benda asing yang tidak larut dan tidak dapat melalui saringan mesin. Adanya kotoran di dalam karet yang relatif tinggi dapat mengurangi sifat dinamika yang unggul dari vulkanisat karet alam antara lain warna timbul dan ketahanan retak lenturnya. Kotoran tersebut juga mengganggu pada pembuatan vulkanisat tipis. Kadar kotoran dari bekuan sangat dipengaruhi oleh proses pengolahan yang dilakukan (Setyamidjaya, 1993) seperti penambahan bahan-bahan pengisi kedalam karet pada waktu pengolahan. Penabahan ekstrak sari mengkudu dengan perlakuan tanpa pemeraman menunjukkan kadar kotoran sebesar 0,01 hingga 0,09 dan penambahan ekstrak sari mengkudu dengan perlakuan pemeraman menunjukkan kandungan kotoran pada lateks berkisar antara 0,02 hingga 0,04.Berdasarkan uji lanjut DMRT, perlakuan ekstrak mengkudu dengan pemeraman dan tanpa pemeraman mempengaruhi adar kotoran lateks yang dihasilkan. Dimana kandungan kadar kotoran pada lateks dengan perlakuan penambahan sari mengkudu sudah sesuai standat SIR-20-1990 yaitu 0,20\%.

\section{Kadar Air Lump}

Hasil penelitian menunjukkan kadar air lump dapat dilihat pada tabel 4 . 
Tabel 4. Nilai Kadar Kotoran Lump

\begin{tabular}{|c|c|c|}
\hline $\begin{array}{c}\text { Penambahan } \\
\text { Ekstrak Mengkudu }\end{array}$ & Tanpa Pemeraman & $\begin{array}{c}\text { Melalui Pemeraman } \\
\mathbf{7 ~ H a r i}\end{array}$ \\
\hline $80 \mathrm{ml}$ & $0,01^{\mathrm{d}}$ & $0,04^{\mathrm{b}}$ \\
$90 \mathrm{ml}$ & $0,09^{\mathrm{a}}$ & $0,02^{\mathrm{c}}$ \\
$100 \mathrm{ml}$ & $0,09^{\mathrm{a}}$ & $0,02^{\mathrm{c}}$ \\
\hline Kontrol & \multicolumn{2}{|c|}{$0,01^{\mathrm{d}}$} \\
\hline
\end{tabular}

Ket : Angka yang diikuti kode huruf yang berbeda menunjukkan adanya perbedaan yang nyata pada taraf signifikan $5 \%$.

\section{Tabel 5. Nilai Kadar Air Lump}

\begin{tabular}{|c|c|c|}
\hline $\begin{array}{c}\text { Penambahan } \\
\text { Ekstrak Mengkudu }\end{array}$ & Tanpa Pemeraman & $\begin{array}{c}\text { Melalui Pemeraman } \\
\mathbf{7 ~ H a r i}\end{array}$ \\
\hline $80 \mathrm{ml}$ & $30,61^{\mathrm{e}}$ & $39,42^{\mathrm{c}}$ \\
$90 \mathrm{ml}$ & $29,06^{\mathrm{f}}$ & $41,78^{\mathrm{a}}$ \\
$100 \mathrm{ml}$ & $28,83^{\mathrm{g}}$ & $41,34^{\mathrm{b}}$ \\
\hline Kontrol & \multicolumn{2}{|c|}{$31,33^{\mathrm{d}}$} \\
\hline
\end{tabular}

Ket : Angka yang diikuti kode huruf yang berbeda menunjukkan adanya perbedaan yang nyata pada taraf signifikan $5 \%$.

Penambahan ekstrak sari mengkudu dengan perlakuan tanpa pemeraman dan pemeraman sebanyak 0 $\mathrm{ml}, \quad 80 \mathrm{ml} . \quad 90 \quad \mathrm{ml}$ dan $\quad 100 \mathrm{ml}$ menunjukkan pengaruh terhadap kandungan kadar air lateks yang dihasilkan. Dimana kandungan kadar air dengan perlakuan sari mengkudu tanpa peram lebih kecil yaitu berkisar 28,83\% hingga $30,61 \%$ jika dibandingan dengan penambahan ekstrak sari mengkudu dengan pemeraman yaitu berkisar 39,42 $\%$ hingga $41,78 \%$. Lateks akan menggumpal jika muatan listrik diturunkan (dehidrasi), $\mathrm{pH}$ lateks diturunkan (penambahan asam $\mathrm{H}+$ ) dan penambahan elektrolit. (Abednego, 1981). Koagulasi lateks adalah peristiwa terjadinya perubahan fase sol menjadi gel dengan bantuan koagulan. Koagulasi lateks secara dehidrasi dilakukan dengan menambah bahan atau zat menyerap lapisan molekul air di sekeliling partikel karet yang bersifat sebagai pelindung pada lateks, zat yang dapat digunakan misalnya alkohol, aseton, dan sebagainya. Pada 
penyimpanan 24 jam pada sari mengkudu dengan pemeraman dan 36 jam pada sari mengkudu matang mengalami peningkatan berat. Hal ini diduga pada saat itu terjadi peningkatan produksi asam laktat sementara produksi alkohol mengalami penurunan diakibatkan oleh oksidasi lebih lanjut alkohol menjadi asam organik misalnya asam cuka. (Amar, 2000).Berdasarkan uji lanjut DMRT, bahwa perlakuan penambahan ekstrak sari mengkudu dengan perlakuan pemeraman dan tanpa pemeraman mempengaruhi hasil analisa kadar air lateks yang dihasilkan

\section{KESIMPULAN}

Pengaruh variasi sari mengkudu terhadap mutu lateks :

1. Varisai sari mengkudu berpengaruh terhadap mutu plastistas awal (Po) lateks yang dihasilkan yaitu dengan rerata berkisar antara 24,00 hingga 29,33, Standat Rubber Indonesia yaitu maksimum 30

2. Variasi mengkudu berpengaruh terhadap plastisitas retensi indeks (PRI) yang dihasilakn yaitu berkisar antara 65,00 hingga 84,00 sesuai Standar Rubber Indonesia yaitu minimum 40

3. Variasi sari mengkudu berpengaruh terhadap kadar abu yang dihasilakn yaitu berkisar antara $0,21 \%$ hingga $0,44 \%$ sesuai Standar Rubber Indonesia yaitu maksimum 1,0\%

4. Variasi sari mengkudu berpengaruh terhadap kadar kotoran yang dihasilakn yaitu berkisar antara 0,01\% hingga 0,09\% sesuai Standar Rubber Indonesia yaitu maksimum $0,20 \%$

5. Variasi sari mengkudu berpengaruh terhadap kadar air yang berkisar antara $28,83 \%$ hingga $41,78 \%$.

\section{DAFTAR PUSTAKA}

Anonim. 2013. Penentuan Kadar Air dan Kadar Abu. http://realitassyamsul.blogspot.co $\mathrm{m} / 2013 / 02 /$ penentuan-kadar-airdan-kadar-abu.html

Aalbersberg, W.G.L, Sabina, H., dan A.S. Wirian. 1993. Journal of Herbs, Spices and Medicinal Plants 2 (1): 51-54

Amar, Abu. 2000. Analisa Mikroorganisme, Kandungan Alkohol, dan Asam Lemak Sari Buah Mengkudu dengan Gas Chromatography.

Budiman, S. 1983. Rencana Perbaikan Pengolahan Karet Rakyat dalam Perbaikan Mutu expor. Kelompok Teknologi Pengolahan Hasil Riset Peneltian Perkebunan Sungei Putih.

Heyne, K. 1987. Tumbuhan Berguna Indonesia III. Badan Penelitian dan Pengembagan Kehutanan, Jakarta: 1749-1789

Kartowardoyo, S. 1980. Penggunaan Wallace-Platimeter Untuk Penentuan KarakteristikKarakteristik Pamatangan Karet 
Alami. Universitas Gadjah Mada. Yogyakarta

Khairina Safitri. 2009. Pengaruh Ekstark Belimbing Wuluh (Averrhoa bilimbi L) Sebagai Penggumpal Lateks terhadap Mutu Karet. Skripsi. 2009

Ompusungguh, $\mathrm{M}$ dan Darussamin, A. 1989. Penggolahan Umum Lateks. Balai Penelitian Perkebunan Sungih Putih.

Rizky Hardiyanty, Ade Heri Suheri, Farida Ali. 2013. Pemanfaatan Sari Mengkudu Sebagai Bahan Penggumpal Lateks. Jurusan Teknik Kimia Fakultas Teknik Universitas Sriwijaya

Setyamidjaja, D.1993. Karet. Kanisius. Yogyakarta

Sinclair, R.D., Ryan T.J. 2007. Proteolytic enzymes in wound healing : the role of enzymatic debridement. Aust. J Derm 35 (1) : 35

Tim Penulis PS. 1999. Karet, Starategi Pemasaran Tahun 2000. Budidaya dan Pengolahan. Cetakan Keenam. Penebar Swadaya. Jakarta

Waha, M.G.2002. Sehat Denagan Mengkudu (editor Listiyani Wijayanti). Penerbit PT. Mitra Sitta Kaleh, Jakarta.

Walujono, K dan Kartowardoyo, S. 1970 . Kemungkinan pengolahan Karet Remah di Indonesia dan Pembahasan Berbagai Proses Karet Butiran Karet Remah . PT Soeroengan. Jakarta

Zahara.2005. Pengaruh Campuran Pengawet (Amonia-Asam Borat) Terhadap Nilai Plastis Awal dan Plastis Retensi Indeks (PRI) Karet Dengan penggumpalan Asam Asetat. Skripsi Jurusan Kimia. FMIPA USU 